\title{
Perspectives on testicular sex cord-stromal tumors and those composed of both germ cells and sex cord-stromal derivatives with a comparison to corresponding ovarian neoplasms
}

Lawrence M. Roth MD ${ }^{* 1}$, Bingjian Lyu MD³, Liang Cheng MD ${ }^{* 1,2}$

Department of Pathology and Laboratory Medicine ${ }^{1}$ and Urology ${ }^{2}$, Indiana University School of Medicine, Indianapolis, IN 46202; Department of Pathology ${ }^{3}$, Women's Hospital, School of Medicine, Zhejiang University, 310003, China.

Running Head: Perspectives on testicular sex cord-stromal tumors

Keywords: Testis; Ovary; Sex cord-stromal tumors; Gonadoblastoma; Mixed germ cell- sex cord stromal tumor; Tumorigenesis.

Address correspondence to: Lawrence M. Roth MD, Department of Pathology, Indiana University School of Medicine, Van Nuys Medical Science Building 128, 635 Barnhill Drive, Indianapolis, IN 46202, USA; lroth@iupui.edu or Liang Cheng, MD, Department of Pathology, Indiana University School of Medicine, Indianapolis, IN 46202; liang_cheng@yahoo.com

Disclosures: This research did not receive any specific grant from funding agencies in the public, commercial, or not-for-profit sectors. No conflict of interest exists.

This is the author's manuscript of the article published in final edited form as:

Roth, L. M., Lyu, B., \& Cheng, L. (2017). Perspectives on testicular sex cord-stromal tumors and those composed of both germ cells and sex cord-stromal derivatives with a comparison to corresponding ovarian neoplasms. Human Pathology. https://doi.org/10.1016/j.humpath.2017.04.009 


\section{Highlights}

- Sex cord-stromal tumors are the second most frequent category of testicular neoplasms.

- They account for approximately 2-5\% of testicular neoplasms in adults.

- Both genetic and epigenetic factors account for their differences from ovarian SCSTs.

- Undifferentiated gonadal tissue is the precursor of classical gonadoblastoma.

- The most recent evidence strongly supports the existence of testicular MGC-SCST. 
Summary Sex cord-stromal tumors (SCSTs) are the second most frequent category of testicular neoplasms, accounting for approximately $2-5 \%$ of cases. Both genetic and epigenetic factors account for the differences in frequency and histologic composition between testicular and ovarian SCSTs. For example, large cell calcifying Sertoli cell tumor and intratubular large cell hyalinizing Sertoli cell neoplasia occur in the testis but have not been described in the ovary. In this article, we discuss recently described diagnostic entities as well as inconsistencies in nomenclature used in the recent World Health Organization classifications of SCSTs in the testis and ovary. We also thoroughly review the topic of neoplasms composed of both germ cells and sex cord derivatives with an emphasis on controversial aspects. These include "dissecting gonadoblastoma" and testicular mixed germ cell-sex cord stromal tumor (MGC-SCST). The former is a recently described variant of gonadoblastoma that sometimes is an immediate precursor of germinoma in the dysgenetic gonads of patients with a disorder of sex development. Although the relationship of "dissecting gonadoblastoma" to the previously described undifferentiated gonadal tissue is complex and not entirely resolved, we believe that it is preferable to continue to use the term undifferentiated gonadal tissue for those cases that are not neoplastic and are considered to be the precursor of classical gonadoblastoma. Although the existence of testicular MGC-SCST has been challenged, the most recent evidence supports its existence; however, testicular MGC-SCST differs significantly from ovarian examples due to both genetic and epigenetic factors. 


\section{Introduction}

Sex cord-stromal tumors are the second most frequent category of testicular neoplasms, accounting for approximately $2-5 \%$ of cases in adults; however, they make up approximately $25 \%$ of cases that occur in infants and children [1]. The incidence of sex cord-stromal tumors is lower in the testis than in the ovary, and the frequency of the different histological types varies substantially between the gonads [2,3]. In the ovary, sex cord-stromal tumors account for approximately $6 \%$ of all primary ovarian neoplasms, and about half of these are in the fibromathecoma group [4]. The sex cord-stromal tumor category consists of neoplasms that are composed of granulosa cells, fibroblasts, theca cells, Sertoli cells, or Leydig cells, either singly or in various combinations.

Both genetic and epigenetic factors account for the significant differences in frequency and histologic composition between the different types of testicular and ovarian sex cord-stromal tumors. Thus, testicular sex cord-stromal tumors more frequently are composed of Sertoli or Leydig cells, whereas ovarian examples are composed more frequently of granulosa or theca cells. Paradoxically, however, Sertoli-Leydig cell tumor is rare in the testis, but accounts for $0.5 \%$ of all ovarian neoplasms [4]. Juvenile-type granulosa cell tumor is rare, accounting for $<0.5 \%$ of all testicular sex cord-stromal tumors; however, it is the most common testicular neoplasm in the first 6 months of life, and almost all cases occur in the first decade [1]. Although exceptions exist, tumors that are less differentiated or contain a sex cord component are more likely to show clinically aggressive behavior than those that are better differentiated or composed of only stromal elements. Precursor lesions for neoplasms in the sex cord-stromal tumor category have not been identified.

The latest World Health Organization (WHO) classification of tumors of the testis divides sex cord-stromal tumors into 2 categories: 1) pure sex cord or pure stromal tumors and 2) those that are composed of an admixture of sex cord and stromal elements [1]. Although the nomenclature would suggest that both adult and juvenile types of granulosa cell tumor are pure 
neoplasms, in reality, each type sometimes contains a neoplastic theca cell component. We prefer to divide sex cord-stromal tumors into those showing predominantly testicular, ovarian, or indeterminate differentiation (Table). Although the nomenclature for testicular and ovarian sex cord-stromal tumors is similar for the most part, certain nuances exist. For example, the equivalent of testicular Sertoli cell tumor, not otherwise specified (NOS) is simply Sertoli cell tumor in the ovary because, thus far, no other types have been described. Leydig cell tumor and Sertoli cell tumor are the two most common sex cord-stromal tumors in adult men, although both neoplasms are, in fact, uncommon. Several histological types of ovarian sex cord-stromal tumors are characterized by somatic DICERI hotspot mutations; however, such mutations were not detected in 15 testicular sex cord-stromal tumors [5].

Although the existence of the entity of mixed germ cell-sex cord stromal tumor (MGCSCST) of the testis has been challenged, the most recent evidence supports its existence; however, testicular neoplasms differ significantly in histological appearance and clinical behavior from ovarian examples due to both genetic and epigenetic factors $[6,7]$.

\section{Sex cord-stromal tumors}

\subsection{Sertoli cell tumor}

Sertoli cell tumor is rare in either gonad; however, testicular examples are about twice as frequent as those occurring in the ovary. Sertoli cell tumor can occur throughout life; but tends to be detected at an older age in men (mean 45 years) than in women (mean 30 years) $[8,9]$.

Clinical symptoms at presentation are usually nonspecific. Hormonal manifestations in patients, such as gynecomastia in males and isosexual pseudoprecocity in girls, are uncommon. Most Sertoli cell tumors are clinically benign; however, approximately $7 \%$ of testicular examples have metastases at presentation, whereas $11 \%$ ( 3 of 27 cases) of stage I ovarian tumors had pelvicabdominal recurrences within 9-36 months [8-10]. In the current WHO classification of testicular tumors, 3 histological variants of Sertoli cell tumor are recognized: Sertoli cell tumor, NOS, large 
cell calcifying Sertoli cell tumor, and intratubular large cell hyalinizing Sertoli cell neoplasia [1]. Sertoli cell tumor, NOS occurs in either sex, whereas the 2 other subtypes have not been described in the ovary; thus, it is unnecessary to subtype ovarian Sertoli cell tumors $[1,11]$. The histological appearance of Sertoli cell tumor, NOS of the testis and ovarian Sertoli cell tumor is strikingly similar; however, it is more difficult to establish a consistent morphological profile of ovarian Sertoli cell tumor because of the existence of more mimics. Immunohistochemistry is generally required for the diagnosis of ovarian Sertoli cell tumors, but it is of limited value in the distinction of ovarian Sertoli cell tumor from granulosa cell tumor, where morphological features remain the mainstay for diagnosis, particularly their patterns of cellular arrangement and their nuclear appearance. Recent observations indicate that molecular studies can greatly aid in this distinction [12-15].

\subsubsection{Sertoli cell tumor, NOS}

Testicular Sertoli cell tumor is about twice as common as ovarian examples. Sertoli cell tumor, NOS demonstrates CTNNB1 mutations (the gene that encodes. $\beta$-catenin) in $>70 \%$ of neoplasms $[1,15]$. About $40 \%$ of cases show gain in the X chromosome [16]. Sertoli cell tumor, NOS is usually well circumscribed and tan-white to yellow on macroscopic examination (Fig. 1A). A lobular or nodular appearance at low magnification is distinctive in the betterdifferentiated testicular and ovarian tumors. Histological examination typically shows a spectrum ranging from a well-differentiated tubular pattern to a diffuse solid proliferation. Rarely, alveolar or retiform patterns are seen. Lymphocytic infiltrate in testicular Sertoli cell tumor can occasionally lead to the mistaken diagnosis of seminoma [1]. Sertoli cell tumors usually have pale to eosinophilic cytoplasm but sometimes consists of lipid-rich cells, and the term lipid-rich Sertoli cell tumor is appropriate for those neoplasms composed entirely of lipid-rich cells $[8,9]$. This variant, however, is observed mostly in the ovary and is associated with isosexual pseudoprecocity in girls. 
Because testicular Sertoli cell tumor, NOS contains variable amounts of lipid; such neoplasms are no longer considered to be a separate entity (Fig. 1B) [17]. We recently encountered a case of lipid-rich Sertoli cell tumor, NOS with signet ring cells, an unusual finding (Fig. 1C). Two similar cases were reported as signet-ring stromal tumor of the testis [18, 19]. Although the World Health Organization referenced the latter cases, a category of signet-ring stromal tumor of the testis was not included in the latest classification of testicular tumors [1]. We believe that the 2 cases previously reported as signet-ring stromal cell tumor of the testis are more accurately classified as Sertoli cell tumor, NOS with a lipid-rich pattern and signet ring cells.

Signet ring stromal cell tumor of the ovary differs significantly from the above-described testicular cases in that the former arises from spindle-shaped immature gonadal stromal cells and the vacuoles in the signet ring cells are hydropic rather than containing lipid [20, 21]. The term signet ring stromal cell tumor was chosen specifically to indicate origin of the neoplasm from ovarian stroma. Lipid-containing signet ring cells have previously been described in different types of ovarian sex cord-stromal tumors, including thecoma, and sclerosing stromal tumor [20, 21].

In the testis, sclerosing Sertoli cell tumor, although originally classified separately, is now considered to be a variant of Sertoli cell tumor, NOS [1, 22]. Sclerosing Sertoli cell tumor is rare in the testis; it has not been reported as a separate entity in the ovary, but has been clearly illustrated $[8,9]$. This testicular variant is typically small $(80 \%<2 \mathrm{~cm})$ and well circumscribed. In most cases, it is characterized by solid or hollow tubules and/or long anastomosing cords in a hypocellular, densely sclerotic stroma. By definition, at least $50 \%$ of the neoplasm must consist of hyalinized stroma in order to establish the diagnosis of this variant [22]. Entrapped seminiferous tubules are frequently found in the neoplasm.

Sclerosing Sertoli cell tumors $<2 \mathrm{~cm}$ in greatest dimension and lacking histological features associated with malignancy have a negligible risk of metastasis and are adequately managed by orchiectomy alone [22]. Only 2 malignant examples have been reported, one 
displaying histological malignancy including cytologic atypia, frequent mitoses, vascular invasion, and invasive extratesticular growth, whereas another was clinically aggressive with bone metastasis and the subsequent death of the patient from disease [22,23]. The occurrence of mutations of the CTNNB1 gene and nuclear displacement of $\beta$-catenin in both Sertoli cell tumor, NOS and its sclerosing variant support their close relationship $[1,15]$.

Two or more of the following features: tumor size $\geq 5 \mathrm{~cm}$, moderate to severe nuclear atypia, 5 or more mitoses per 10 high power fields, vascular invasion, and tumor necrosis are associated with adverse outcomes in testicular Sertoli cell tumor, NOS; however, only two of these features, moderate to severe nuclear atypia and 5 or more mitoses per 10 high power fields are useful indicators for a poor prognosis in corresponding ovarian neoplasms (Figs. 1D-F) $[8,9]$.

Sertoli cell tumor, NOS must be distinguished from macroscopic Sertoli cell nodule. The latter lesion either presents as a palpable testicular mass or is found incidentally on ultrasound and measures $\geq 0.5 \mathrm{~cm}[24,25]$. The largest macroscopic Sertoli cell nodule thus far published measured $1.7 \mathrm{~cm}$ in greatest dimension and contained numerous spermatogonia [26].

Histologically, macroscopic Sertoli cell nodule is composed of clusters of altered seminiferous tubules separated by testicular interstitial tissue. The altered tubules contain an admixture of immature Sertoli cells, variable numbers of spermatogonia, and globular deposits of basement membrane material at all levels of the involved tubules.

\subsubsection{Large cell calcifying Sertoli cell tumor}

Large cell calcifying Sertoli cell tumor has only been reported in the testis. Cases typically occur in teenage boys and young adults, and about $60 \%$ are sporadic [1]. Approximately $40 \%$ of cases are bilateral, and these are nearly always associated with the Carney complex. Germline mutations in the PRKARIA gene on the long arm of chromosome 17 are found in a high proportion of Carney complex type 1-associated neoplasms and occasionally in apparently sporadic examples [27]. 
Histologically, the tumor cells are arranged in solid tubules, nests, cords, or clusters. Calcification is the only distinctive macroscopic feature (Fig. 2A). As indicated by its name, the neoplastic cells are large and have abundant eosinophilic cytoplasm (Fig. 2B). About one-half of the neoplasms contain an intratubular component. The cytological features closely resemble those of Leydig cell tumor; however, the presence of calcification, the absence of Reinke crystals, the prominent tubular architecture, and larger cell size are sufficient for the differential diagnosis [28]. Clinically aggressive behavior is uncommon. Malignant large cell calcifying Sertoli cell tumors have 2 or more of the following features: extratesticular spread, tumor size $\geq 4 \mathrm{~cm}$, mitoses $>3$ per 10 high power fields, significant nuclear atypia, necrosis, lymphatic or blood vascular invasion $[29,30]$.

\subsubsection{Intratubular large cell hyalinizing Sertoli cell neoplasia}

Intratubular large cell hyalinizing Sertoli cell neoplasia is a distinct variant of Sertoli cell tumor that occurs almost exclusively in boys with the Peutz-Jeghers syndrome [31]. Patients usually present with gynecomastia. Germline mutation in the STK11 gene is the causation of the Peutz-Jeghers syndrome and is also central to the development of large cell hyalinizing Sertoli cell neoplasia [1]. These intratubular lesions are small, bilateral, and multifocal. They have a patchy distribution and are characterized by expanded seminiferous tubules that are filled with large eosinophilic or vacuolated Sertoli cells and globular deposits of basement membrane material that extend from the thickened peritubular basement membrane (Figs. 2C and D). Calcification occurs occasionally in the basement membrane material. Because of its typical intratubular location, metastases are unlikely to occur. Uncommonly, these neoplasms invade the testicular interstitium and, thereby, histologically resemble large cell calcifying Sertoli cell tumor.

The corresponding tumor in girls with the Peutz-Jeghers syndrome is known as sex cord tumor with annular tubules [10]. The histological differences between testicular intratubular large cell hyalinizing Sertoli cell neoplasia and ovarian sex cord tumor with annular tubules are likely 
related to both genetic and epigenetic factors.

\subsection{Leydig cell tumor}

Leydig cell tumors comprise 1-3\% of testicular neoplasms and can occur at any age, but are more common in prepubertal boys and in men aged 30 to 60 years. These neoplasms can produce androgens or estrogens, and about $30 \%$ of patients present with gynecomastia. Leydig cell tumors are always benign in boys, whereas $10 \%$ of the cases in adults are malignant $[32,33]$.

On the sectioned surface, these neoplasms are red-brown to yellow. Histologically, seminiferous tubules are often entrapped at the periphery of the tumor (Fig. 3A). Most neoplasms have a diffuse pattern and are composed of polygonal cells with abundant eosinophilic cytoplasm and uniform round nuclei with small nucleoli (Fig. 3B). Reinke crystals are identified in about $30 \%$ of cases, and lipofuscin pigment is observed in about 15\% [1]. Malignant Leydig cell tumors are typically large ( $\geq 4 \mathrm{~cm})$, have infiltrating margins, invade lymphatics or blood vessels, have a high mitotic rate ( $\geq 3$ per 10 high power fields, and exhibit nuclear atypia (Figs. 3C and D) [30]. In a series of 40 cases of testicular Leydig cell tumor, all 5 clinically malignant cases had 4 or more of the above histological features [32].

\subsection{Sertoli-Leydig cell tumor}

Sertoli-Leydig cell tumors are exceptionally rare in the testis, whereas they account for $0.5 \%$ of ovarian neoplasms [10]. Six previously reported putative cases that contained both tubular and Leydig cell components were recently reviewed, however, the diagnosis could not be definitely confirmed because of the lack of immunocytochemical stains and high quality images [30]. At least 1 documented well-differentiated Sertoli-Leydig cell tumor involving the testis has been reported [34]. Furthermore, a moderately differentiated neoplasm was recently illustrated in the recent WHO Classification of Tumours of the Urinary System and Male Genital Organs (see Fig. 4.63, p.228) [1]. 
Because of its rarity in the testis, our knowledge of this neoplasm comes almost exclusively from the ovarian entity. Sertoli-Leydig cell tumors can be divided into three main subtypes based on their degree of differentiation: well, moderately, or poorly differentiated. The moderately and poorly differentiated neoplasms sometimes contain retiform or heterologous components or both. Well-differentiated Sertoli-Leydig cell tumors are characterized by a lobular structure composed of hollow or solid tubules and a mature fibrous stromal component containing a substantial number of Leydig cells. Moderately differentiated neoplasms show a conspicuously nodular growth pattern. Both Sertoli cells and Leydig cells are mixed in the nodules and may display varying degrees of architectural and cytological immaturity. Leydig cells are much less common than in the well-differentiated neoplasms. Poorly differentiated Sertoli-Leydig cell tumors have a diffuse pattern resembling fibrosarcoma. By definition, they should have at least small foci of diagnostic elements that are composed of Sertoli cells and Leydig cells. Heterologous elements occur in approximately $20 \%$ of Sertoli-Leydig cell tumors, but not in the well-differentiated type. They may manifest as glands or cysts lined by gastrointestinal epithelium, and/or heterologous mesenchymal elements such as fetal-type cartilage or embryonal rhabdomyosarcoma. The epithelial components sometimes contain goblet cells and argentaffin cells that can occasionally form a goblet cell or an insular carcinoid. Exceptionally, hepatoid or renal tissue may be encountered in Sertoli-Leydig cell tumors. About $15 \%$ of moderately or poorly differentiated Sertoli-Leydig cell tumors contain retiform elements. The retiform pattern usually makes up only a portion of the neoplasm, but occasionally the entire tumor is retiform. Retiform areas typically show a network of irregularly branching, elongated slit-like tubules and cysts. Papillae or polypoid structures can project into these structures.

\subsection{Granulosa cell tumor}

Granulosa cell tumors are currently classified into adult and juvenile types based on their histological appearance; they are much more common in the ovary than in the testis. Granulosa 
cell tumors of either adult or juvenile type are almost invariably unilateral. The adult type accounts for $95 \%$ of ovarian granulosa cell tumors, whereas, in the testis, the 2 types have a more balanced distribution. In the testis, juvenile-type granulosa tumor is the most common neoplasm in the first 6 months of life.

Testicular granulosa cell tumor is rare, although corresponding ovarian neoplasms are the most common malignant sex cord-stromal tumor, accounting for approximately $12 \%$ of cases [4, 30]. Although the term granulosa cell tumor connotes that it is composed purely or at least predominantly of granulosa cells, in reality, both the juvenile and adult types occasionally have a neoplastic theca cell component.

\subsubsection{Adult-type granulosa cell tumor}

Adult-type granulosa cell tumor is rare, accounting for $<0.5 \%$ of testicular sex cordstromal tumors [1]. The neoplasms are almost invariably unilateral. Testicular and ovarian adulttype granulosa cell tumors not only have a similar FOXL2 codon 134.

Macroscopically, adult-type granulosa cell tumor typically appears as a solid, cystic, or solid and cystic mass with a yellow-tan hue on the sectioned surface. Histologically, the diffuse and microfollicular patterns, the latter with Call-Exner bodies, are the most common in testicular examples [35]. Granulosa cell tumors occasionally show a mixed cell population of granulosa cells, theca cells and fibroblasts. Exceptionally, the granulosa cells are luteinized. The neoplastic granulosa cells typically have pale nuclei that frequently show a longitudinal groove. Bizarre nuclei have not, thus far, been reported in testicular examples. Features that can be associated with aggressive behavior include size $>4 \mathrm{~cm}$, infiltrative borders, and lymphatic or blood vascular invasion [35].

\subsubsection{Juvenile-type granulosa cell tumor}

Juvenile-type granulosa cell tumor is rare, accounting for $<0.5 \%$ of all testicular SCSTs; 
however, it is the most common testicular neoplasm in the first 6 months of life, and almost all cases occur in the first decade [1]. All neoplasms reported to date have been benign.

On macroscopic examination, these tumors are well circumscribed and vary from solid to cystic. The sectioned surface varies from yellow to tan-white. Histological examination shows a solid pattern with focal follicular formation or a uniformly follicular pattern (Fig. 4A). The follicles contain basophilic or eosinophilic fluid that stains with mucicarmine and are lined by an inner layer of granulosa cells sometimes surrounded by an outer layer of neoplastic theca cells (Figs. 4B). Occasionally, the granulosa cells appear to be luteinized. The neoplastic granulosa cells are distinguished from those of the adult type in that they have round dense nuclei that lack nuclear grooves. Mitotic figures are more frequent than in the adult type. Classical Call-Exner bodies and pale or grooved nuclei are not encountered. The primary differential diagnosis is juvenile-type yolk sac tumor. Juvenile-type granulosa cell tumor is almost always positive for steroidogenic factor 1, whereas SALL4, glypican-3, and alpha-fetoprotein are negative in the neoplastic granulosa cells.

\subsection{Tumors in the fibroma group}

Although the fibroma-thecoma group accounts for at least $4 \%$ of ovarian tumors, $<30$ cases have been reported in the testis [36-38]. In the interest of scientific parsimony, we prefer the terminology recommended in the WHO classification of ovarian tumors [11]. To the best of our knowledge, no cases of thecoma or sclerosing stromal tumor have been reported in the testis; therefore, the term fibrothecoma used in the latest WHO classification of testicular tumors does not seem appropriate [1]. Thus, we diagnose testicular neoplasms in this group simply as fibroma or cellular fibroma. None of the tumors reported thus far have been clinically aggressive [36, 37].

These neoplasms occur mostly in middle aged or elderly men and are almost invariably unilateral. On the sectioned surface, they are well circumscribed and white. Entrapped seminiferous tubules are occasionally encountered at the periphery of the neoplasm (Fig. 5A). 
Histological examination of typical and cellular fibroma shows oval to spindle-shaped cells arranged in a fascicular or storiform pattern sometimes containing fibrous bands or hyaline plaques [36] (Fig. 5B). The nuclei of cellular fibromas are more densely packed and mitotically active, containing as many as 5 mitotic figures per 10 high power fields, and hyaline plaques also can occur [37] (Figs. 5C and D).

\subsection{Myoid gonadal stromal tumor}

Myoid gonadal stromal tumor is classified as an emerging entity in the latest WHO classification of testicular tumors despite the fact that it was first reported as such in 1991; to date, $<10$ cases have been reported [1]. Although this tumor can occur at almost any age, the typical presentation is a testicular mass in a young or middle-aged man. All cases reported to date have had an uneventful follow up. Thus far, no corresponding neoplasm has been described in the ovary.

Myoid gonadal stromal tumor is composed of densely packed spindle-shaped cells arranged in short fascicles that have features of both smooth muscle and gonadal stroma [39]. The existence of such a neoplasm is not altogether unexpected since ovarian stroma and granulosa cell tumor, thecoma, and fibroma are all known to show smooth muscle differentiation to varying degrees, however for the same reason we consider the concept to be problematic [40].

In 1977, Evans and Glick [41] reported the first case as an unusual gonadal stromal tumor that occurred in a 4-year old boy. In, 1984, Greco et al. [42] reported 2 cases as testicular stroma tumor with myofilaments. In 1991, Weidner [43] introduced the term myoid gonadal stromal tumor, and, in 2012, Du et al. [44] of the same group compared their findings in another case to the normal adjacent peritubular myoid cells and observed similar immunoreactivity. They believed that myoid gonadal stromal tumor shows peritubular myoid cell differentiation.

In 1996, Nistal et al. [45] reported a case as fusocellular gonadal stroma tumor of the testis with epithelial and myoid differentiation and suggested origin from peritubular myoid cells. 
The challenge of establishing a diagnosis of myoid gonadal stromal tumor was exemplified by Jones et al. [36] who interpreted the aforementioned case as a fibroma of gonadal stromal origin. In 1997, Renshaw et al. [46] reported 4 cases of unclassified sex cord-stromal tumors of the testis with a predominance of spindle cells, although their case 4 was composed entirely of elongated spindle cells reminiscent of smooth muscle differentiation on hematoxylin and eosin staining. In areas of all of their cases, however, reticulin enveloped variably sized aggregates of tumor cells rather than individual cells confirming the identification of a sex cord component.

In 2014, Kao and Ulbright [39] reported 3 cases of myoid gonadal stromal tumor and reviewed the prior literature; they concluded that the neoplasm originates from intertubular primitive mesenchymal cells that undergo myogenic differentiation rather than from peritubular myoid cells. They specifically excluded predominantly spindle cell tumors with sex cord differentiation appreciable on hematoxylin and eosin or reticulin stains from the myoid gonadal stromal category.

We believe that further study of this rare and enigmatic tumor is necessary to verify its existence as a distinct entity, to establish its histogenesis, and to develop reliable histological and immunocytochemical criteria that can distinguish it from other pure testicular stromal neoplasms, particularly testicular fibroma.

\subsection{Unclassified and mixed sex cord-stromal tumors}

Unclassified and mixed sex cord-stromal tumors are rare in the testis. They are best considered to be in the indeterminate category because they lack predominant differentiation in either the testicular or ovarian direction. Although they can occur at any age, they typically present in middle-aged or elderly men [1]. Approximately one-third of cases, however, present in children [30]. The usual presentation is a painless testicular mass.

The unclassified type consists of sex cord elements having features intermediate between Sertoli and granulosa cells as well as stromal elements (Figs. 6A and B). The mixed type consists 
of various combinations of sex cord elements that show differentiation either toward Sertoli cells or granulosa cells from area to area. Reticulin stains can be helpful in the diagnosis of unclassified or mixed sex cord stromal tumor since the sex cord elements have inconspicuous reticulin fibers, whereas reticulin surrounds individual stromal cells. Occasional neoplasms in either category are clinically malignant, and these display similar histological features to those used to distinguish malignant Sertoli cell or Leydig cell tumors from benign examples [1]. To the best of our knowledge, no case corresponding to gynandroblastoma has been described in the testis, although such neoplasms occur rarely in the ovary.

\section{Tumors composed of both germ cells and sex cord-stromal derivatives}

In the latest classification of testicular neoplasms, the WHO includes a category of tumors containing both germ cells and sex cord-stromal elements immediately after that of sex cord-stromal tumors [1]. We include both gonadoblastoma and MGC-SCST in this category, although the latter was excluded from the fourth edition of the WHO classification of tumors of the testis. Because of differing viewpoints in the literature regarding the existence of testicular MGC-SCST, the Editors deemed that there was insufficient evidence at the time of publication to include the category of MGC-SCST in the WHO classification [47]. However, we believe that the findings in recent articles strongly support the existence of testicular MGC-SCST as a distinct entity $[7,48,49]$.

\subsection{Gonadoblastoma}

\subsubsection{Clinical findings}

In 1953, Scully [50] first described classical gonadoblastoma. Later, in a seminal article, he reported a series of 74 cases [51]. Gonadoblastoma occurs almost entirely in the dysgenetic gonads of individuals who have a disorder of sex development associated with a Y-chromosome or part thereof [52]. Approximately $20 \%$ of gonadoblastomas occur in phenotypic males, who are 
most often $<20$ years of age [30]. The clinical presentation in the latter cases commonly includes cryptorchidism, hypospadias, and gynecomastia [51]. Gonadoblastoma occurs predominantly in phenotypic females with gonadal dysgenesis and an abnormal karyotype, but occurs exceptionally in apparently normal females with a $46 \mathrm{XX}$ karyotype [11]. The most common predisposing conditions are 45, X/46, XY partial gonadal dysgenesis, 46, XY complete gonadal dysgenesis, and 46, XY disorder of sex development, formerly known as male pseudohermaphroditism [52, 53]. In a patient with a disorder of sex development, at least 1 gonad is developmentally abnormal; however, histological confirmation would not be possible if the gonad has been completely replaced by neoplasm.

The gonadoblastoma susceptibility region on the short arm of the Y chromosome (GBY) is the only oncogenic region on the human $\mathrm{Y}$ chromosome and predisposes the dysgenetic gonads of XY individuals to develop an in situ tumor; TSPY1 is the putative gene [52, 54, 55]. If a gonad in a patient who has a disorder of sex development contains germ cells with delayed maturation and also harbors the TSPY1 gene, the cells may undergo transformation to gonadoblastoma [56]. The germ cells that have delayed maturation express OCT4 [57].

\subsubsection{Histology and immunocytochemistry}

Classical gonadoblastoma is a noninvasive neoplasm composed of cellular nests or islands surrounded by gonadal stroma of variable cellularity. About $40 \%$ of gonadoblastomas are bilateral [1]. Histologically, the nests are composed of germ cells intimately admixed with immature sex cord derivatives, and the latter often surround hyaline basement membrane deposits

(Fig. 7A). In some instances, stromal steroid cells are noted. The germ cells of individual cases of gonadoblastoma are heterogeneous, being composed of both mature and immature germ cells [58]. The mature germ cells resemble spermatogonia and express TSPY1, whereas the immature germ cells resemble those of germinoma, express OCT4, and are considered to be the precursor of the malignant germ cell neoplasms associated with gonadoblastoma [59]. 
Frequently, classical gonadoblastoma shows involutional changes including deposits of basement membrane material, hyalinization, and calcification (Figure 7B). Rarely, the involutional changes are extensive resulting in a calcified mass without any viable neoplastic cells. We refer to such cases as involuted gonadoblastoma; although such cases were originally described as "burnt out" gonadoblastoma [51].

\subsubsection{Undifferentiated gonadal tissue}

Undifferentiated gonadal tissue is defined as gonadal tissue containing germ cells not enclosed in seminiferous tubules or follicles that either resides without apparent organization in a background of cellular gonadal stroma or is organized together with sex cord elements into cordlike structures $[57,60]$. Undifferentiated gonadal tissue occurs exclusively within dysgenetic gonads and has been proposed as the precursor of classical gonadoblastoma [57, 61]. In $67 \%$ of cases of classical gonadoblastoma that contained adjacent gonad, undifferentiated gonadal tissue was identified [57]. The germ cells in both undifferentiated gonadal tissue and classical gonadoblastoma are heterogeneous; they can express TSPY1, OCT4, or can co-express the two [57].

\subsubsection{Relationship of classical gonadoblastoma to malignant germ cell tumors}

Classical gonadoblastoma represents the precursor of germinoma and other invasive malignant germ cell neoplasms in patients who have a disorder of sex development [62]. Thus, classical gonadoblastoma can be interpreted as an in situ germ cell neoplasm that occurs in dysgenetic gonads that are predisposed to malignant transformation, most commonly to germinoma [59]. In $60 \%$ of cases of classical gonadoblastoma, an associated malignant germ cell tumor is encountered, and in $80 \%$ of the latter cases, the neoplasm is germinoma (Figs. 7B) [4]. However, patients with classical gonadoblastoma sometimes develop a more aggressive germ cell tumor, including yolk sac tumor, embryonal carcinoma, or immature teratoma [63]. SALL4 is 
diffusely expressed in the germ cells of both gonadoblastoma and germinoma (Figs. 7C). Ulbright and Young [64] recently reviewed gonadoblastoma and other selected aspects of gonadal pathology in patients that have a disorder of sex development.

\subsection{5. "Dissecting gonadoblastoma"}

In a recent investigation of 50 cases of classical gonadoblastoma, Kao et al. [65] described a morphologic variant in 38 cases that they referred to as "dissecting gonadoblastoma." They considered "dissecting gonadoblastoma" to be a variant of classical gonadoblastoma that showed similar immunohistochemical findings. In their model, classical gonadoblastoma was believed to be the intermediate lesion between the cord-like/anastomosing phase and the solid/expansile form of "dissecting gonadoblastoma."

The prime importance of this variant is that several growth patterns in which the number of sex cord cells appear reduced can be misinterpreted as germinoma [65]. They described 3 patterns: solid expansile, anastomosing, and cord-like. The cord-like pattern can be confused with a similar pattern that has been described in germinoma resulting in more aggressive clinical treatment than necessary (Fig. 7D) [30]. The application of inhibin or steroidogenic factor 1 immunohistochemical stains facilitates the identification of residual sex cord elements and is often useful in distinguishing "dissecting gonadoblastoma" from germinoma [65].

\subsubsection{Distinction of undifferentiated gonadal tissue from "dissecting gonadoblastoma"}

At the present time, the relationship of "dissecting gonadoblastoma" to undifferentiated gonadal tissue is controversial and unresolved. We believe that it is preferable to continue to use the term undifferentiated gonadal tissue for those cases that are considered to be the precursor of gonadoblastoma, as was recommended in the latest WHO classification of testicular tumors (p. 237), and to limit the use of "dissecting gonadoblastoma" to those cases with a solid expansile, cord-like, or other patterns that can be confused with germinoma [1]. We consider clonal 
expansion of germ cells in "dissecting gonadoblastoma" to be the likely immediate precursor of some germinomas, and, therefore, such expansion should be a requirement for the diagnosis of "dissecting gonadoblastoma."

Undifferentiated gonadal tissue has been described morphologically as germ cells with delayed development within immature sex cords or isolated in the interstitium $[57,60]$.

Undifferentiated gonadal tissue is by definition a non-neoplastic process and, therefore, should be distinguished from "dissecting gonadoblastoma," as the latter is a neoplastic process that is sometimes the precursor of germinoma. Although a cord-like pattern is a feature of some examples of undifferentiated gonadal tissue and some "dissecting gonadoblastomas," the distinction can be made histologically by careful examination of other features of "dissecting gonadoblastoma" including an expansive growth pattern and proliferation of transformed germ cells.

\subsection{Mixed germ cell-sex cord stromal tumor}

In contrast to gonadoblastoma, MGC-SCST occurs in phenotypically normal individuals without sex chromosomal abnormalities, and both gonads are developmentally normal [53]. MGC-SCST shows significant differences in frequency, histological appearance, and biological behavior depending on whether the neoplasm originates in the testis or the ovary. Both genetic and epigenetic factors likely account for these dissimilarities.

In 1972, Talerman [66, 67] described separately the first 2 cases of ovarian MGC-SCST. Nearly 10 years later, Bolen [68] reported the first testicular case. Testicular MGC-SCST is often composed of an intimate mixture of germ cells and sex-cord derivatives; however, the germ cells are variable in quantity and distribution, occasionally making the diagnosis challenging.

Only $10 \%$ of cases in girls and women are associated with malignant germ cell tumors, far less than the incidence in classical gonadoblastoma (50-60\%). Intriguingly, testicular cases have not been found to be associated with clinically malignant germ cell tumors to date $[7,69]$. 
However, a case of MGC-SCST in a 7-year-old boy with precocious pseudopuberty contained some histologically and immunohistochemically malignant germ cells resembling those of seminoma as well as immature sex cord elements [70]. The seminoma-like germ cells likely occurred as a result of an additional mutation in the germ cells of the neoplasm.

Macroscopically, testicular MGC-SCSTs are variable in size, well delimited, and solid gray-white on the sectioned surface (Fig. 8A). Testicular MGC-SCSTs often contain entrapped seminiferous tubules in which the germ cells are confined to the basal compartment (Fig. 8B). Occasionally, an intratubular component is identified (Fig. 8C). The intratubular component shows clonal expansion of germ cells and has been shown to be the precursor of invasive MGCSCST in a few cases [7]. In a majority of cases of invasive MGC-SCST, the germ cells form an integral part of the neoplasm (Fig. 8D). Histologically, MGC-SCST lacks the nest-like pattern and the involutional changes of basement membrane deposition, hyalinization, and calcification that are often observed in classical gonadoblastoma.

Although the existence of the entity of MGC-SCST of the testis has been challenged, the most recent evidence strongly supports its occurrence; however, testicular tumors differ significantly from ovarian examples both in their biological behavior and their histological appearance $[6,7,48,49]$.

\subsection{Conclusion}

For the most part, the testis and ovary share similar categories of sex cord-stromal tumors; however, for specific categories, the neoplasms have different frequencies, subtypes, and clinicopathological features. Our knowledge of sex cord-stromal tumors has advanced in recent years incorporating the description of some novel morphological variants, the discovery of the FOXL2 mutation in granulosa cell tumors and some other sex cord-stromal tumors, and DICER1 somatic mutations in several types of ovarian sex cord-stromal tumors, but not so far in similar testicular neoplasms. 
Careful morphologic observations together with detailed clinical information remain fundamental for the diagnosis of gonadal sex cord-stromal tumors and those that have an additional germ cell component. Although our knowledge of the pathobiology and molecular genetics of these neoplasms will increase in the future, incorporation of classical histopathology and immunocytochemistry will result in optimal patient care. Thus, we believe that diagnostic pathologists will play an essential role in this process for the foreseeable future 


\section{Figure Legends}

Fig. 1 Sertoli cell tumor, not otherwise specified (NOS). A, The sectioned surface of the testis contains a small well-circumscribed ovoid white nodule near the tunica albuginea. B, The neoplasm consists of irregular solid tubules within a fibrous stroma. The tumor cells have small, centrally located nuclei and finely vacuolated, lipid-rich cytoplasm (hematoxylin and eosin [H\&E], original magnification, x400). C, Diffusely arranged tumor cells have pale cytoplasm with cytoplasmic vacuolization due to lipid and occasional signet ring cell formation (arrows) (H\&E, x200). Inset, Signet ring cell in the central portion of the field contains a large cytoplasmic vacuole that compresses a bland eccentrically located, crescent-shaped nucleus resembling a signet ring. D, Malignant Sertoli cell tumor. Nodules of tumor infiltrate the rete testis (H\&E, $\mathrm{x} 40$ ). E, The malignant Sertoli cell tumor has a diffuse growth pattern to the left with extensive tumor necrosis to the right (H\&E, x100). F, The malignant Sertoli cell tumor shows moderate nuclear pleomorphism with enlarged nuclei and a distinct nucleolus. Note an abnormal mitotic figure in the upper central portion of the field (arrow) (H\&E, x400).

Fig. 2 Other types of Sertoli cell tumor. A, Large cell calcifying Sertoli cell tumor consists of irregular cords of neoplastic cells, some of which contain mulberry calcifications seen centrally and in the lower left (H\&E, x400). B, The tumor cells have abundant eosinophilic cytoplasm (H\&E, x600). C, Intratubular large cell hyalinizing Sertoli cell neoplasia is composed of expanded seminiferous tubules containing hyaline basement membrane material in a cribriform arrangement. The uninvolved testicular tubules seen above and to the right are atrophic and surrounded by thickened basement membranes $(\mathrm{H} \& \mathrm{E}, \mathrm{x} 100)$. D, The intratubular component consists of enlarged tubules lined by Sertoli cells surrounding hyaline nodules composed of basement membrane material. A cluster of non-neoplastic Leydig cells is present in the right lower portion of the field (H\&E, x200). 
Fig. 3 Leydig cell tumor. A, Histologically benign neoplasm is composed of polygonal cells with abundant eosinophilic cytoplasm surrounding an entrapped seminiferous tubule in the left upper part of the field (H\&E, x200). B, The neoplastic cells have uniform bland nuclei with a small nucleolus and abundant eosinophilic cytoplasm (H\&E, x600). C, Malignant Leydig cell tumor is composed of irregular clusters of neoplastic cells with enlarged pleomorphic nuclei and eosinophilic cytoplasm supported by a delicate vasculature (H\&E, x400). (D) Neoplasm extends into a thin-walled vascular space containing erythrocytes (arrow), (H\&E, x100).

Fig. 4 Juvenile-type granulosa cell tumor. A, Neoplasm forms confluent cystic follicles containing basophilic mucin (H\&E, x100). B, The follicular structures are lined by layers of granulosa cells with small closely packed nuclei surrounded by neoplastic theca cells that have oval to elongated nuclei and indistinct cytoplasm. The granulosa cell nuclei are uniform and dense, lacking nuclear grooves (H\&E, x400).

Fig. 5 Tumors in the fibroma group. A, Fibroma is composed of intersecting fascicles of spindleshaped cells with bland nuclei. Residual testis with seminiferous tubules is seen to the left (H\&E, x100). B, Short fascicles of spindle-shaped neoplastic cells are observed (H\&E, x200). C, Cellular fibroma is composed of tumor cells with high nuclear to cytoplasmic ratios surrounding nodular areas of fibrosis and hyalinization (H\&E, x400). D, The cell nuclei are small, round to oval, densely packed and the cytoplasm is indistinct. Note the mitotic figure in the right upper part of the field (arrow), (H\&E, x400).

Fig. 6 Unclassified sex cord-stromal tumor A, Neoplastic cells are diffusely distributed and closely packed with formation of vague cords (H\&E, x100). (B) The neoplastic cells resemble immature sex cord cells and have round to oval nuclei with small or indiscernible nucleoli and scant indistinct cytoplasm (H\&E, x400). 
Fig. 7 Gonadoblastoma and related neoplasms. A, Classical gonadoblastoma is composed of cellular islands separated by hyaline basement membrane material. The islands are made up of germ cells and sex cord elements. Two types of germ cells are identified. Some germ cells have uniform bland nuclei with small nucleoli and abundant cytoplasm resembling spermatogonia, whereas others have larger nuclei with a prominent nucleolus resembling those of germinoma. The sex cord elements sometimes surround hyaline bodies composed of basement membrane material (H\&E, x600). B, A thin fibrous band separates classical gonadoblastoma containing a mulberry calcification (arrow) in the lower portion of the field from germinoma composed of primitive malignant germ cells with enlarged nuclei and clear cytoplasm in the upper third (H\&E, x400). (C) An island of classical gonadoblastoma in the center of the field is surrounded by germinoma. The germ cell nuclei in both neoplasms express SALL4. The nuclei in the nest of gonadoblastoma vary in size. The smaller nuclei resemble spermatogonia and the larger nuclei are those of germinoma (SALL4, x200). D, "Dissecting gonadoblastoma" composed of small cords of cells in a fibrous stroma in the lower and right portion of the field is separated from germinoma in the upper left by a thick wavy fibrous band (H\&E, x100). Inset. The cords of "dissecting gonadoblastoma" are composed predominantly of germ cells, but a few residual sex cord derivatives can be identified mostly at their periphery.

Fig. 8 Mixed germ cell-sex cord-stromal tumor (MGC-SCST) of the testis. A, The sectioned surface of the testis shows a circumscribed gray-white tumor nodule in the central portion. B, Spermatogonia in the basal compartment of entrapped seminiferous tubules express SALL4; however, in the invasive component of the neoplasm, germ cells were variably distributed, and none were identified in this field (SALL4, x100). C, Intratubular component of MGC-SCST consists of an expanded tripartite tubule composed of numerous transformed spermatogonia with variably sized nuclei and immature sex cord cells surrounded by neoplastic immature sex cord cells (H\&E, x600). D, Invasive MGC-SCST is composed of an admixture of neoplastic immature sex cord cells and transformed germ cells resembling spermatogonia, but with variably sized nuclei that form an integral part of the tumor and (H\&E, x600). 


\section{References}

[1] Moch H, Humphrey PA, Ulbright TM, Reuter VE. Classification of Tumours of the Urinary System and Male Genital Organs. Lyon: International Agency for Research on Cancer (IARC) Press; 2016.

[2] Ulbright TM. Germ cell tumors of the gonads: a selective review emphasizing problems in differential diagnosis, newly appreciated, and controversial issues. Mod Pathol. 2005;18 Suppl 2:S61-79.

[3] Roth LM, Talerman A. Recent advances in the pathology and classification of ovarian germ cell tumors. Int J Gynecol Pathol. 2006;25:305-20.

[4] Clement PB, Young RH. Atlas of Gynecologic Surgical Pathology. 3rd ed. London: Saunders/Elsevier; 2014.

[5] Conlon N, Schultheis AM, Piscuoglio S et al. A survey of DICER1 hotspot mutations in ovarian and testicular sex cord-stromal tumors. Mod Pathol. 2015;28:1603-12.

[6] Ulbright TM, Srigley JR, Reuter VE, Wojno K, Roth LM, Young RH. Sex cord-stromal tumors of the testis with entrapped germ cells: a lesion mimicking unclassified mixed germ cell sex cord-stromal tumors. Am J Surg Pathol. 2000;24:535-42.

[7] Roth LM, Cheng L. On the histogenesis of mixed germ cell-sex cord stromal tumour of the gonads. J Clin Pathol. 2017;70:222-7.

[8] Young RH, Koelliker DD, Scully RE. Sertoli cell tumors of the testis, not otherwise specified: a clinicopathologic analysis of 60 cases. Am J Surg Pathol. 1998;22:709-21.

[9] Oliva E, Alvarez T, Young RH. Sertoli cell tumors of the ovary: a clinicopathologic and immunohistochemical study of 54 cases. Am J Surg Pathol. 2005;29:143-56.

[10] Young RH. Sex cord-stromal tumors of the ovary and testis: their similarities and differences with consideration of selected problems. Mod Pathol. 2005;18 Suppl 2:S8198.

[11] Kurman RJ, Carcangiu ML, Herrington CS, Young RH. WHO Classification of Tumours of Female Reproductive Organs, 4th Edition. Lyon; 2014.

[12] Shah SP, Kobel M, Senz J et al. Mutation of FOXL2 in granulosa-cell tumors of the ovary. N Engl J Med. 2009;360:2719-29.

[13] Kim MS, Hur SY, Yoo NJ, Lee SH. Mutational analysis of FOXL2 codon 134 in granulosa cell tumour of ovary and other human cancers. J Pathol. 2010;221:147-52.

[14] Lima JF, Jin L, de Araujo AR et al. FOXL2 mutations in granulosa cell tumors occurring in males. Arch Pathol Lab Med. 2012;136:825-8.

[15] Perrone F, Bertolotti A, Montemurro G, Paolini B, Pierotti MA, Colecchia M. Frequent mutation and nuclear localization of beta-catenin in Sertoli cell tumors of the testis. Am J Surg Pathol. 2014;38:66-71.

[16] Verdorfer I, Hollrigl A, Strasser U et al. Molecular-cytogenetic characterisation of sex cord-stromal tumours: CGH analysis in Sertoli cell tumours of the testis. Virchows Arch. 2007;450:425-31.

[17] Cheng L, Lyu B, Roth LM. Perspectives on testicular germ cell neoplasms. Hum Pathol 2017;59: 10-25.

[18] Michal M, Hes O, Kazakov DV. Primary signet-ring stromal tumor of the testis. Virchows Arch. 2005;447:107-10.

[19] Kuo CY, Wen MC, Wang J, Jan YJ. Signet-ring stromal tumor of the testis: a case report and literature review. Hum Pathol. 2009;40:584-7.

[20] Roth LM, Ramzy I. Signet ring stromal cell tumor revisited and related signet ring cell lesions of the ovary. Hum Pathol. 2014;45:636-42.

[21] Roth LM, Ramzy I. Perspectives on signet ring stromal cell tumor and related signet ring cell lesions of the gonads. Adv Anat Pathol. 2014;21:443-9.

[22] Kao CS, Kum JB, Idrees MT, Ulbright TM. Sclerosing Sertoli cell tumor of the testis: a 
clinicopathologic study of 20 cases. Am J Surg Pathol. 2014;38:510-7.

[23] Zukerberg LR, Young RH, Scully RE. Sclerosing Sertoli cell tumor of the testis. A report of 10 cases. Am J Surg Pathol. 1991;15:829-34.

[24] Barghorn A, Alioth HR, Hailemariam S, Bannwart F, Ulbright TM. Giant Sertoli cell nodule of the testis: distinction from other Sertoli cell lesions. J Clin Pathol. 2006;59:1223-5.

[25] Vallangeon BD, Eble JN, Ulbright TM. Macroscopic Sertoli cell nodule: a study of 6 cases that presented as testicular masses. Am J Surg Pathol. 2010;34:1874-80.

[26] Roth LM, Czernobilsky B. Macroscopic Sertoli cell nodule of the testis containing numerous spermatogonia. Pathol Res Pract. 2016;212:943-945.

[27] Petersson F, Bulimbasic S, Sima R et al. Large cell calcifying Sertoli cell tumor: a clinicopathologic study of 1 malignant and 3 benign tumors using histomorphology, immunohistochemistry, ultrastructure, comparative genomic hybridization, and polymerase chain reaction analysis of the PRKAR1A gene. Hum Pathol. 2010;41:552-9.

[28] Sato K, Ueda Y, Sakurai A et al. Large cell calcifying Sertoli cell tumor of the testis: comparative immunohistochemical study with Leydig cell tumor. Pathol Int. 2005;55:366-71.

[29] Kratzer SS, Ulbright TM, Talerman A et al. Large cell calcifying Sertoli cell tumor of the testis: contrasting features of six malignant and six benign tumors and a review of the literature. Am J Surg Pathol. 1997;21:1271-80.

[30] Ulbright TM, Young RH. Tumors of the Testis and Adjacent Structures. Silver Spring, MD: American Registry of Pathology; 2013.

[31] Ulbright TM, Amin MB, Young RH. Intratubular large cell hyalinizing Sertoli cell neoplasia of the testis: a report of 8 cases of a distinctive lesion of the Peutz-Jeghers syndrome. Am J Surg Pathol. 2007;31:827-35.

[32] Kim I, Young RH, Scully RE. Leydig cell tumors of the testis. A clinicopathological analysis of 40 cases and review of the literature. Am J Surg Pathol. 1985;9:177-92.

[33] Al-Agha OM, Axiotis CA. An in-depth look at Leydig cell tumor of the testis. Arch Pathol Lab Med. 2007;131:311-7.

[34] Perito PE, Ciancio G, Civantos F, Politano VA. Sertoli-Leydig cell testicular tumor: case report and review of sex cord/gonadal stromal tumor histogenesis. J Urol. 1992;148:8835.

[35] Cornejo KM, Young RH. Adult granulosa cell tumors of the testis: a report of 32 cases. Am J Surg Pathol. 2014;38:1242-50.

[36] Jones MA, Young RH, Scully RE. Benign fibromatous tumors of the testis and paratesticular region: a report of 9 cases with a proposed classification of fibromatous tumors and tumor-like lesions. Am J Surg Pathol. 1997;21:296-305.

[37] Zhang M, Kao CS, Ulbright TM, Epstein JI. Testicular fibrothecoma: a morphologic and immunohistochemical study of 16 cases. Am J Surg Pathol. 2013;37:1208-14.

[38] Burandt E, Young RH. Thecoma of the ovary: a report of 70 cases emphasizing aspects of its histopathology different from those often portrayed and its differential diagnosis. Am J Surg Pathol. 2014;38:1023-32.

[39] Kao CS, Ulbright TM. Myoid gonadal stromal tumor: a clinicopathologic study of three cases of a distinctive testicular tumor. Am J Clin Pathol. 2014;142:675-82.

[40] Santini D, Ceccarelli C, Leone O et al. Smooth muscle differentiation in normal human ovaries, ovarian stromal hyperplasia and ovarian granulosa-stromal cells tumors. Mod Pathol. 1995;8:25-30.

[41] Evans HL, Glick AD. Unusual gonadal stromal tumor of the testis. Case report with ultrastructural observations. Arch Pathol Lab Med. 1977;101:317-20.

[42] Greco MA, Feiner HD, Theil KS, Mufarrij AA. Testicular stromal tumor with myofilaments: ultrastructural comparison with normal gonadal stroma. Hum Pathol. 
$1984 ; 15: 238-43$.

[43] Weidner N. Myoid gonadal stromal tumor with epithelial differentiation (? testicular myoepithelioma). Ultrastruct Pathol. 1991;15:409-16.

[44] Du S, Powell J, Hii A, Weidner N. Myoid gonadal stromal tumor: a distinct testicular tumor with peritubular myoid cell differentiation. Hum Pathol. 2012;43:144-9.

[45] Nistal M, Puras A, Perna C, Guarch R, Paniagua R. Fusocellular gonadal stromal tumour of the testis with epithelial and myoid differentiation. Histopathology. 1996;29:259-64.

[46] Renshaw AA, Gordon M, Corless CL. Immunohistochemistry of unclassified sex cordstromal tumors of the testis with a predominance of spindle cells. Mod Pathol. 1997;10:693-700.

[47] Moch H, Cubilla AL, Humphrey PA, Reuter VE, Ulbright TM. The 2016 WHO Classification of Tumours of the Urinary System and Male Genital Organs-Part A: Renal, Penile, and Testicular Tumours. Eur Urol. 2016;70:93-105.

[48] Michal M, Vanecek T, Sima R et al. Mixed germ cell sex cord-stromal tumors of the testis and ovary. Morphological, immunohistochemical, and molecular genetic study of seven cases. Virchows Arch. 2006;448:612-22.

[49] Roth LM, Cheng L. Mixed germ cell-sex cord stromal tumor of the testis with an intratubular component: a problem in differential diagnosis. Hum Pathol. 2016;51:51-6.

[50] Scully RE. Gonadoblastoma; a gonadal tumor related to the dysgerminoma (seminoma) and capable of sex-hormone production. Cancer. 1953;6:455-63.

[51] Scully RE. Gonadoblastoma. A review of 74 cases. Cancer. 1970;25:1340-56.

[52] Cools M, Looijenga LH, Wolffenbuttel KP, Drop SL. Disorders of sex development: update on the genetic background, terminology and risk for the development of germ cell tumors. World J Pediatr. 2009;5:93-102.

[53] Jacobsen JK, Talerman A. Atlas of Germ Cell Tumours. Copenhagen: Munksgaard; 1989.

[54] Tsuchiya K, Reijo R, Page DC, Disteche CM. Gonadoblastoma: molecular definition of the susceptibility region on the Y chromosome. Am J Hum Genet. 1995;57:1400-7.

[55] Lau Y, Chou P, Iezzoni J, Alonzo J, Komuves L. Expression of a candidate gene for the gonadoblastoma locus in gonadoblastoma and testicular seminoma. Cytogenet Cell Genet. 2000;91:160-4.

[56] Cools M, van Aerde K, Kersemaekers AM et al. Morphological and immunohistochemical differences between gonadal maturation delay and early germ cell neoplasia in patients with undervirilization syndromes. J Clin Endocrinol Metab. 2005;90:5295-303.

[57] Cools M, Stoop H, Kersemaekers AM et al. Gonadoblastoma arising in undifferentiated gonadal tissue within dysgenetic gonads. J Clin Endocrinol Metab. 2006;91:2404-13.

[58] Jørgensen N, Muller J, Jaubert F, Clausen OP, Skakkebaek NE. Heterogeneity of gonadoblastoma germ cells: similarities with immature germ cells, spermatogonia and testicular carcinoma in situ cells. Histopathology. 1997;30:177-86.

[59] Kersemaekers AM, Honecker F, Stoop H et al. Identification of germ cells at risk for neoplastic transformation in gonadoblastoma: an immunohistochemical study for OCT3/4 and TSPY. Hum Pathol. 2005;36:512-21.

[60] Lepais L, Morel Y, Mouriquand P et al. A novel morphological approach to gonads in disorders of sex development. Mod Pathol. 2016;29:1399-1414.

[61] Beaulieu Bergeron M, Lemieux N, Brochu P. Undifferentiated gonadal tissue, Y chromosome instability, and tumors in XY gonadal dysgenesis. Pediatr Dev Pathol. 2011;14:445-59.

[62] Pauls K, Franke FE, Buttner R, Zhou H. Gonadoblastoma: evidence for a stepwise progression to dysgerminoma in a dysgenetic ovary. Virchows Arch. 2005;447:603-9.

[63] Simon RA, Laughlin TS, Nuccie B, Wang N, Rothberg PG, Wang X. A 46 XY 
phenotypic female adolescent with bilateral gonadal tumors consisting of five different components. Int J Gynecol Pathol. 2008;27:407-11.

[64] Ulbright TM, Young RH. Gonadoblastoma and selected other aspects of gonadal pathology in young patients with disorders of sex development. Semin Diagn Pathol. 2014;31:427-40.

[65] Kao CS, Idrees MT, Young RH, Ulbright TM. "Dissecting gonadoblastoma" of Scully: A morphologic variant that often mimics germinoma. Am J Surg Pathol. 2016;40:1417-23.

[66] Talerman A. A mixed germ cell-sex cord stroma tumor of the ovary in a normal female infant. Obstet Gynecol. 1972;40:473-8.

[67] Talerman A. A distinctive gonadal neoplasm related to gonadoblastoma. Cancer. 1972;30:1219-24.

[68] Bolen JW. Mixed germ cell-sex cord stromal tumor. A gonadal tumor distinct from gonadoblastoma. Am J Clin Pathol. 1981;75:565-73.

[69] Talerman A, Roth LM. Recent advances in the pathology and classification of gonadal neoplasms composed of germ cells and sex cord derivatives. Int J Gynecol Pathol. 2007;26:313-21.

[70] Hettinger CA, Cheville JC, Lteif AN, Bradley NA, Kramer SA. Precocious puberty in a 7-year-old boy: a novel case. J Pediatr Urol. 2009;5:412-4. 

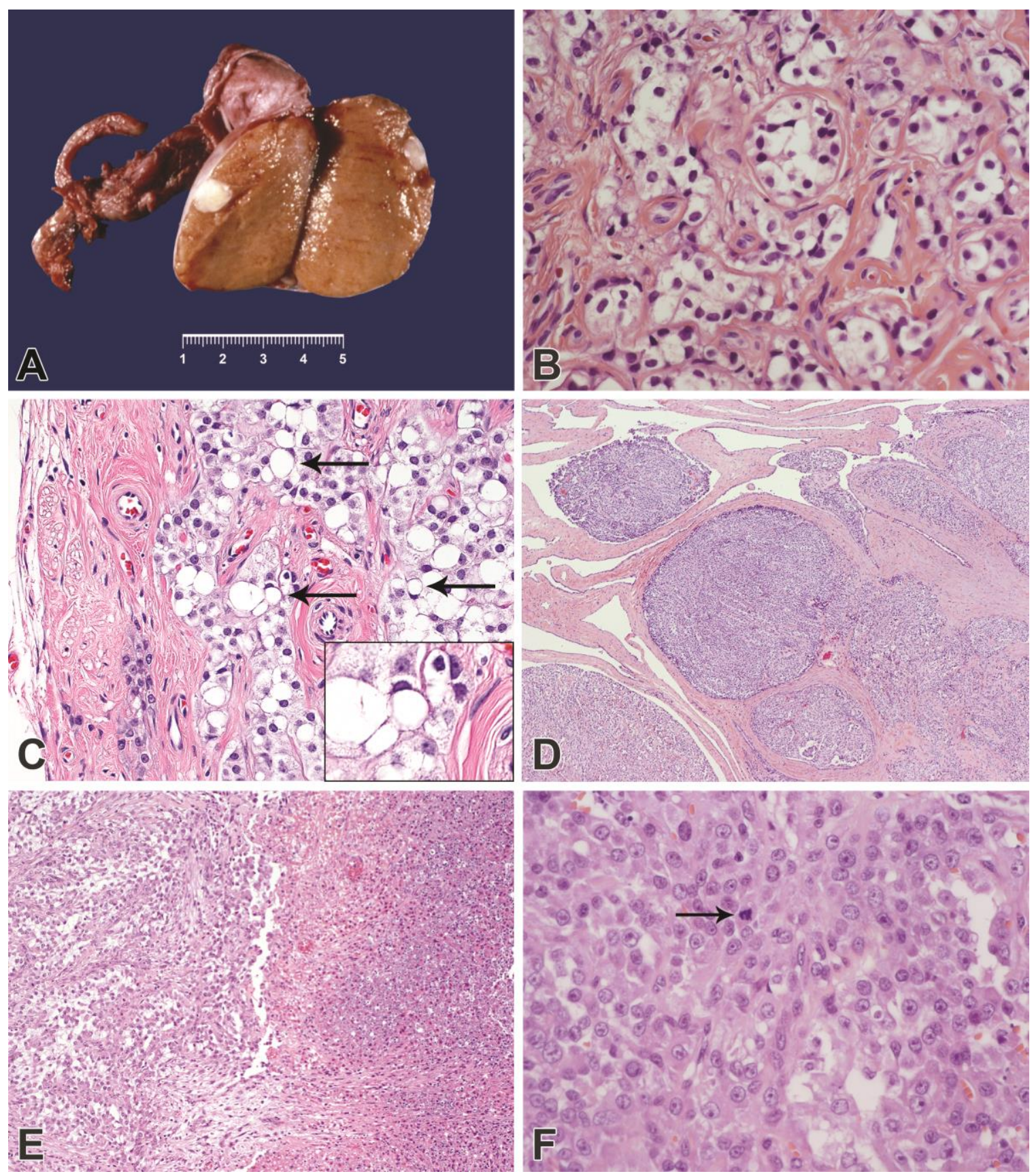

Fig. 1 

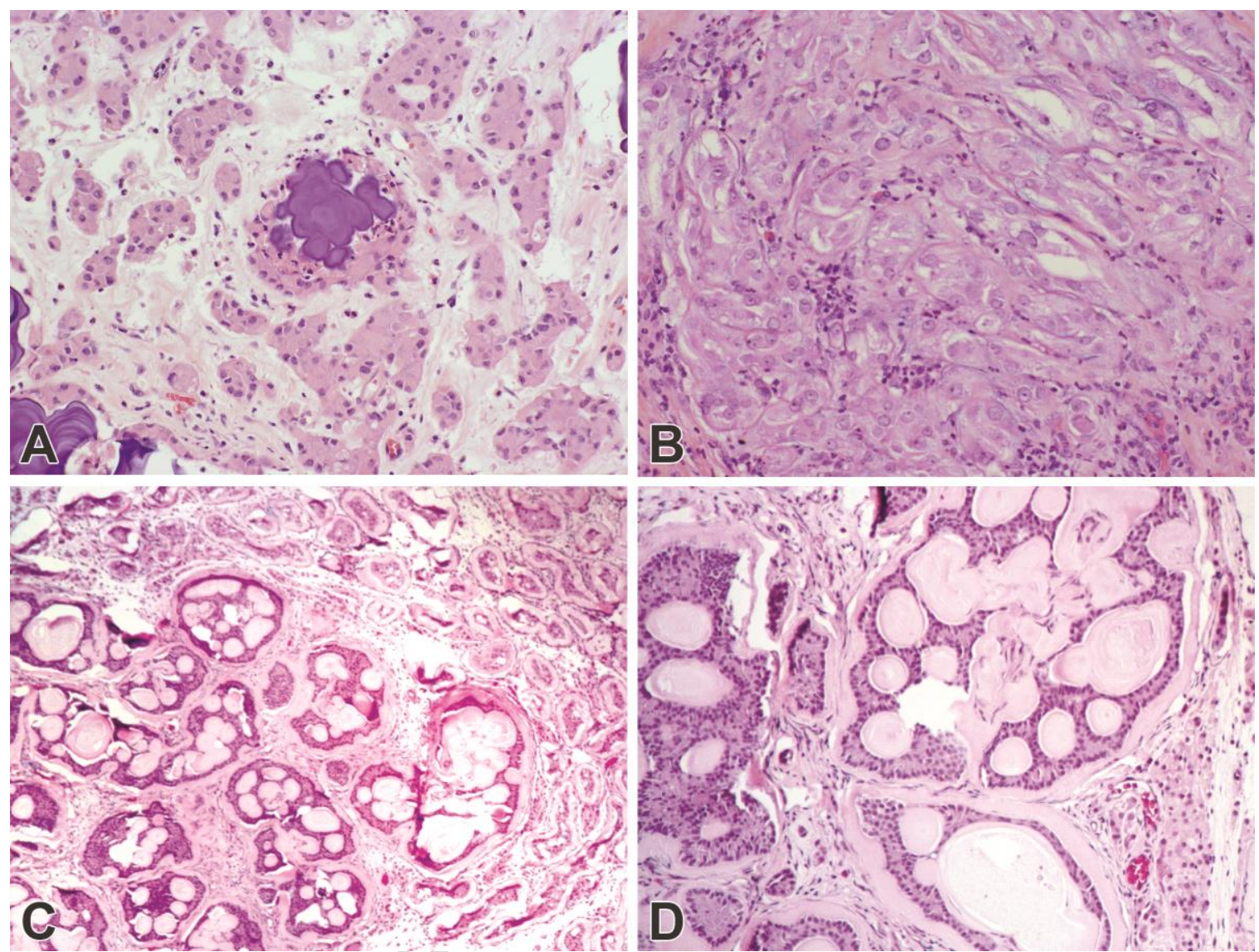

Fig. 2

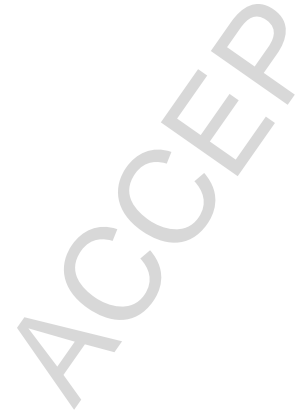



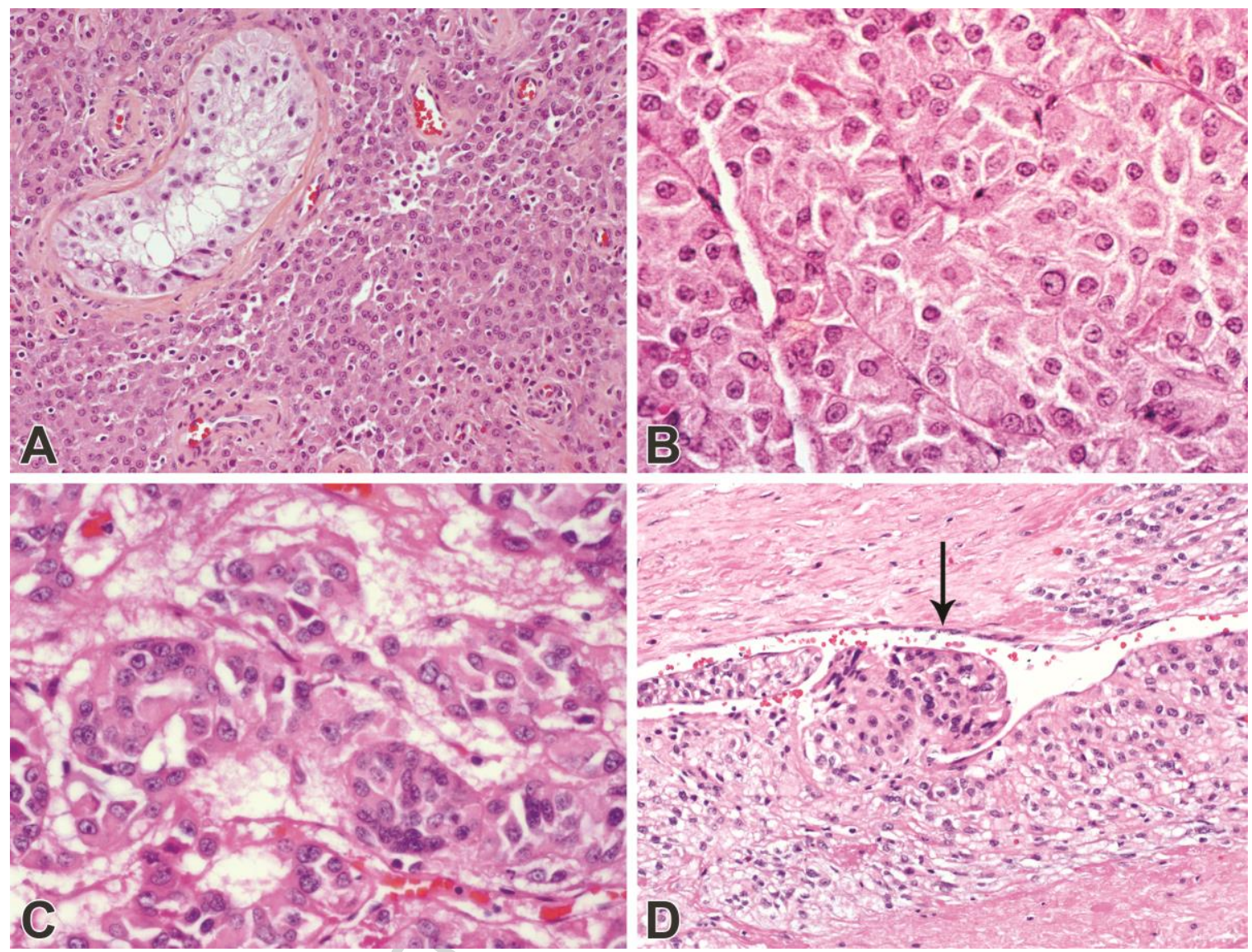

Fig. 3

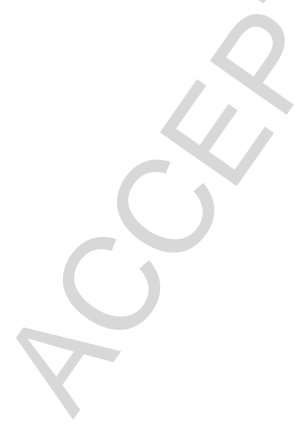



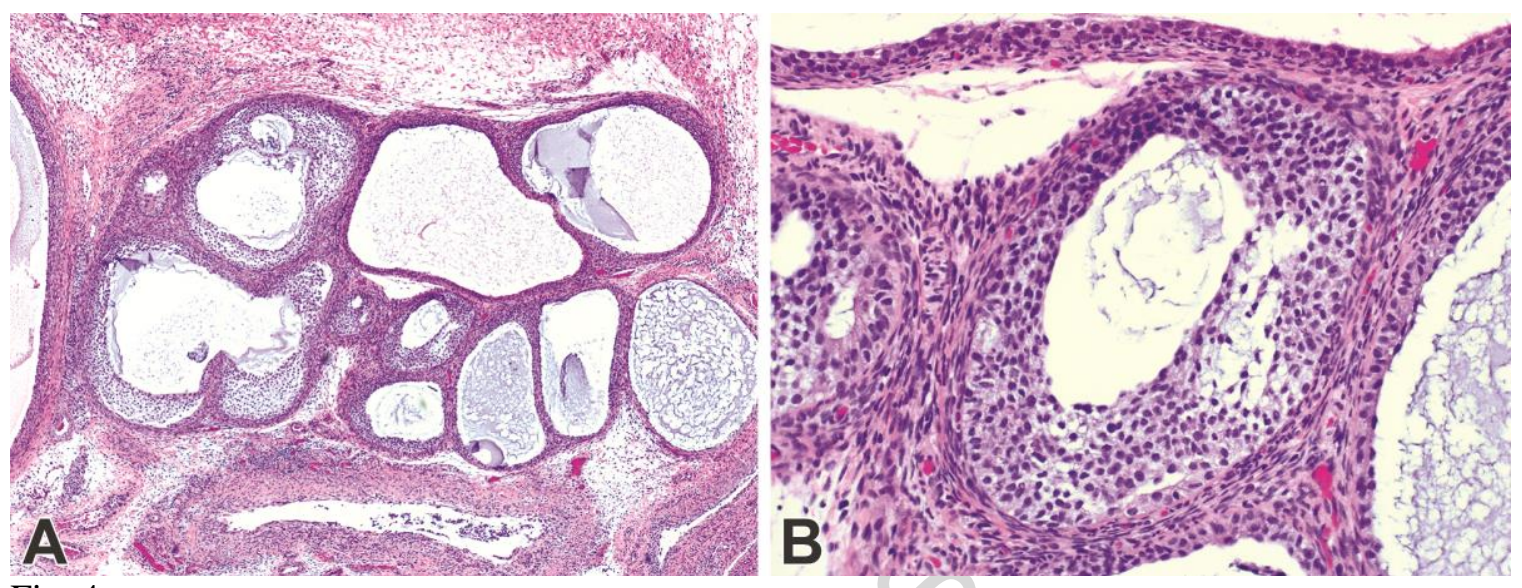

Fig. 4 

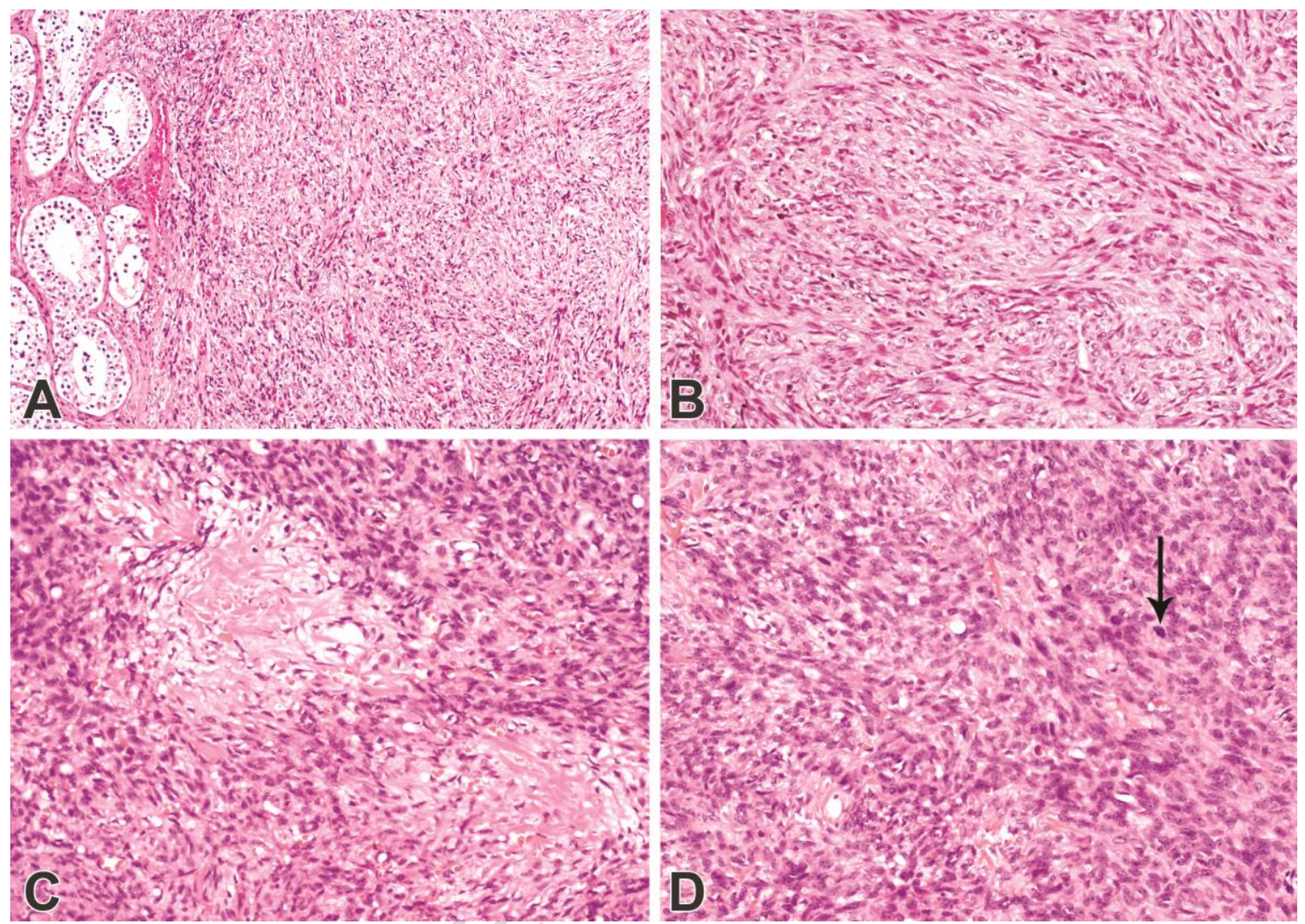

Fig. 5

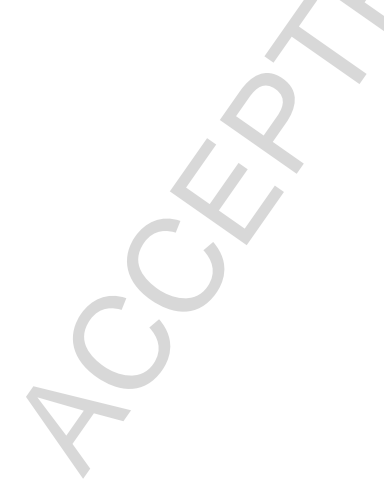



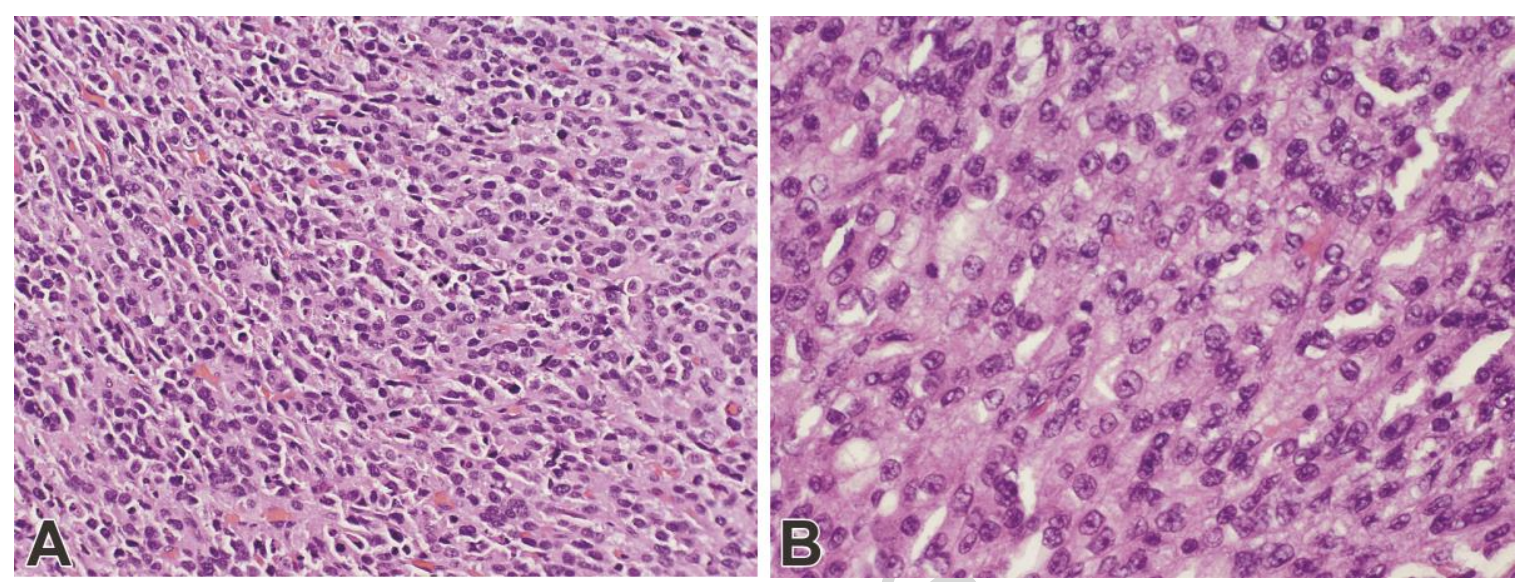

Fig. 6

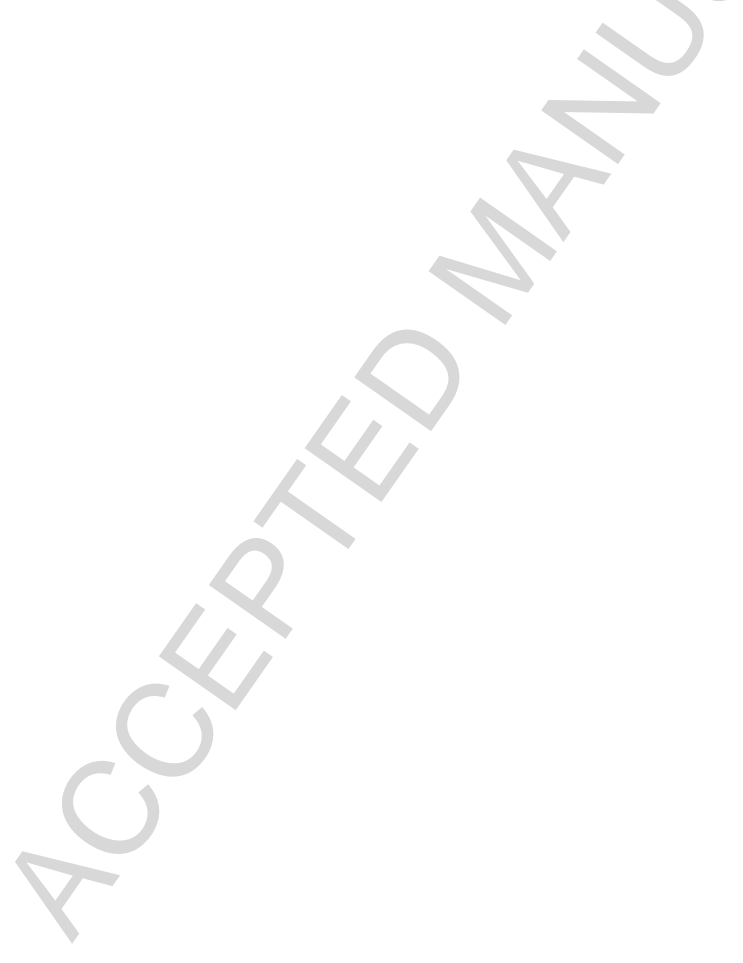




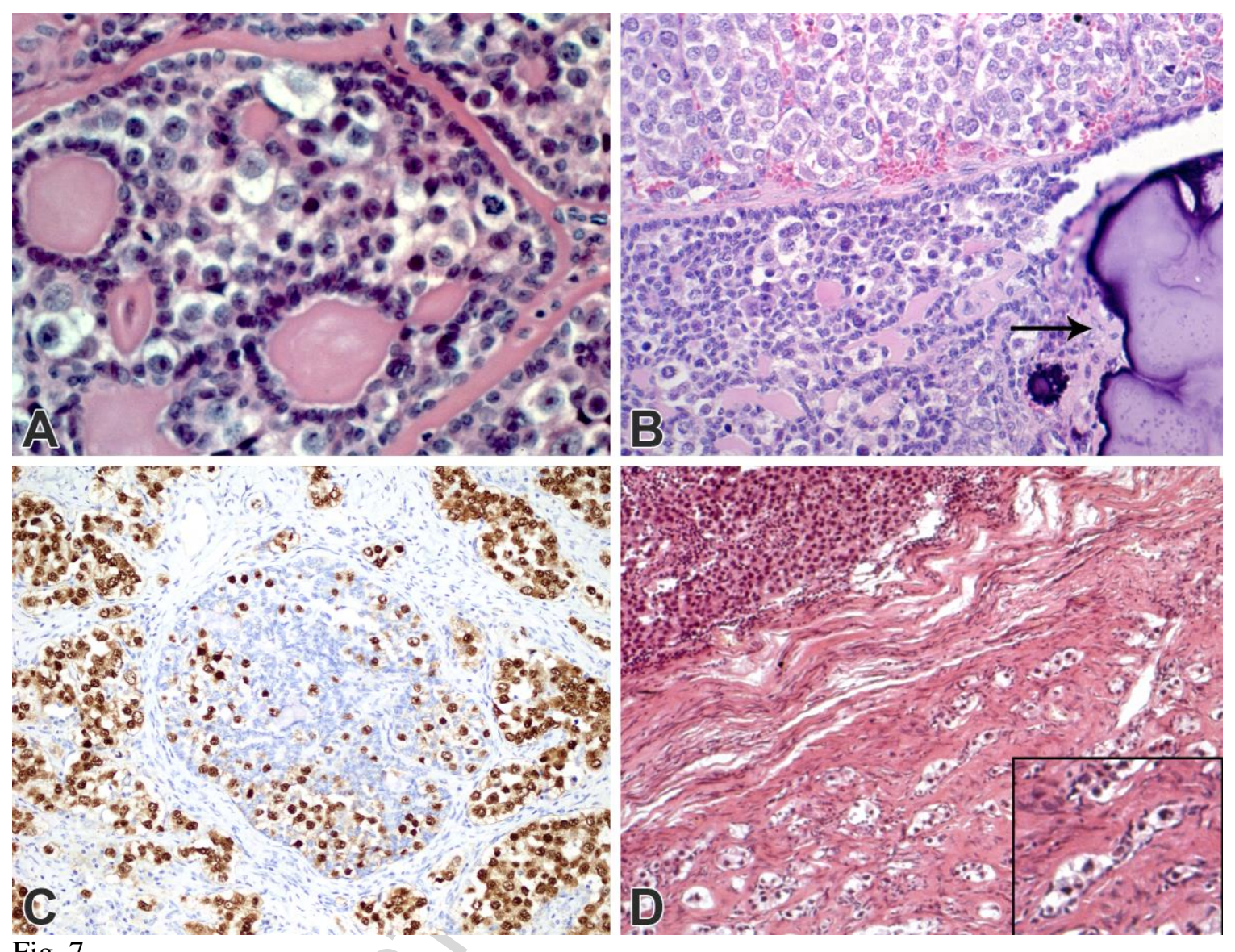

Fig. 7

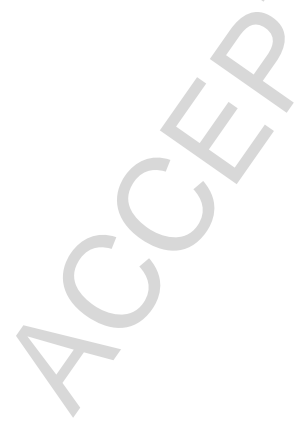



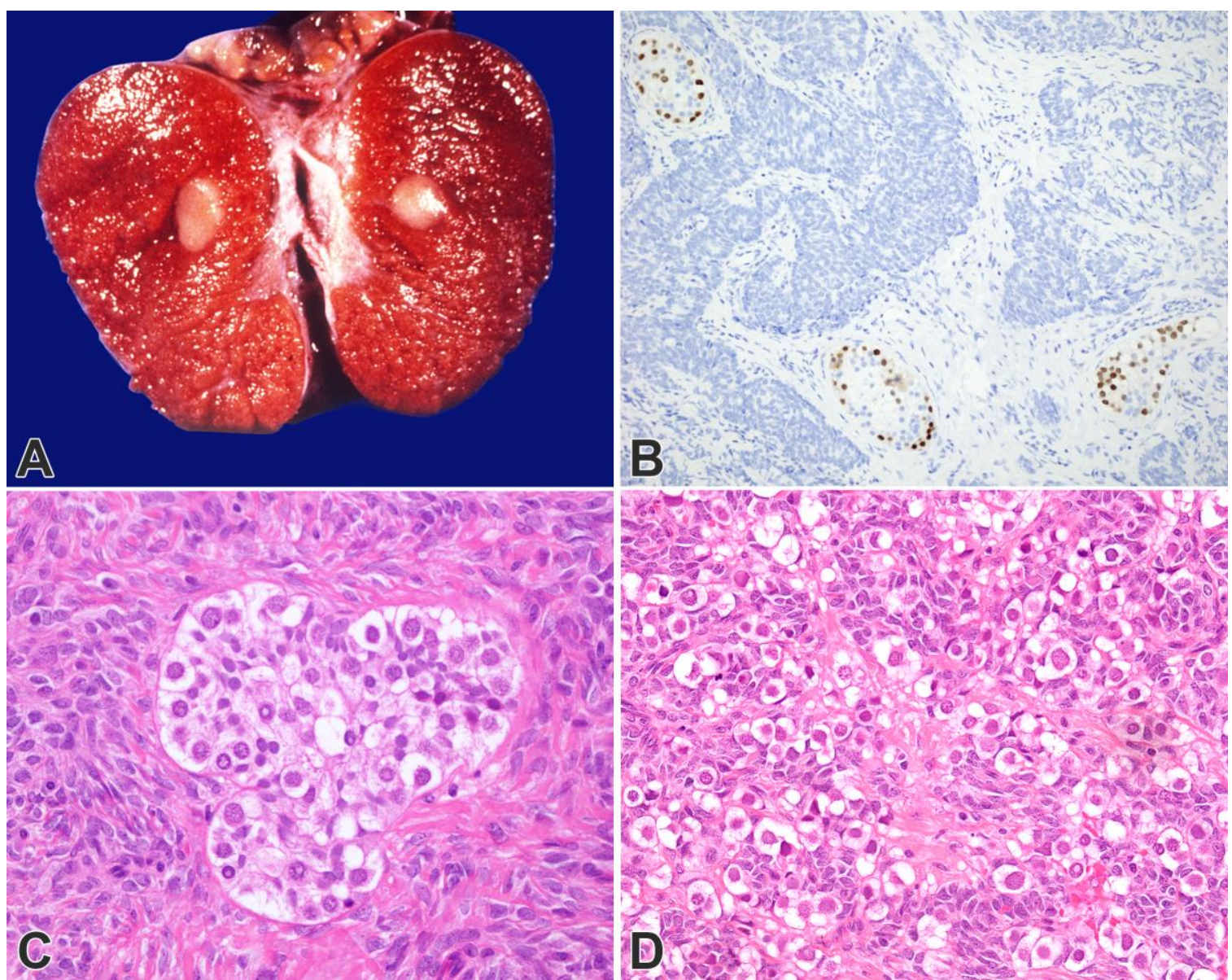

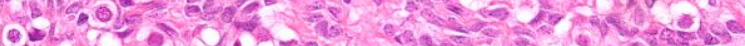

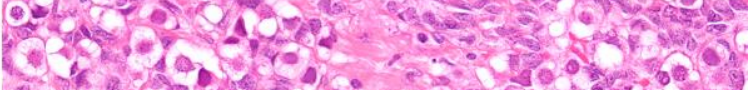

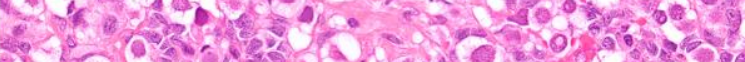

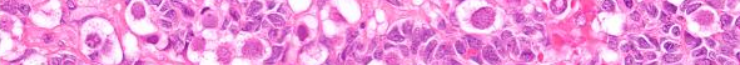

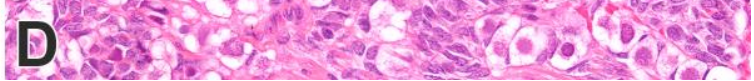

Fig. 8

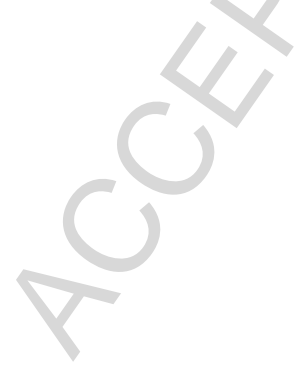


Table 1. Classification of testicular sex cord-stromal tumors according to histologic differentiation

\begin{tabular}{|c|c|c|}
\hline Differentiation & Type of tumor & Subtype \\
\hline \multirow[t]{9}{*}{ Testicular } & Sertoli cell tumor & Not otherwise specified (NOS) \\
\hline & & Malignant \\
\hline & Large cell calcifying Sertoli cell tumor & \\
\hline & Intratubular large cell Sertoli cell neoplasia & \\
\hline & Leydig cell tumor & Not otherwise specified (NOS) \\
\hline & & Malignant \\
\hline & Sertoli-Leydig cell tumor & Well differentiated \\
\hline & & Moderately differentiated \\
\hline & & Poorly differentiated \\
\hline \multirow[t]{4}{*}{ Ovarian } & Granulosa cell tumor & Adult type \\
\hline & & Juvenile type \\
\hline & Fibroma & Not otherwise specified (NOS) \\
\hline & & Cellular \\
\hline \multirow[t]{4}{*}{ Indeterminate } & Myoid gonadal stromal tumor* & \\
\hline & Sex cord-stromal tumor & Unclassified type \\
\hline & & Mixed type \\
\hline & & Malignant \\
\hline
\end{tabular}

* Emerging entity 